\title{
興味ある臨床經過をとれるクルッケン ベルグ氏卵巢腫瘍の 2 例に就レて
}

\author{
Two Cases of Krukenberg's Ovarial Tumor with \\ an Interesting Clinical Process.
}

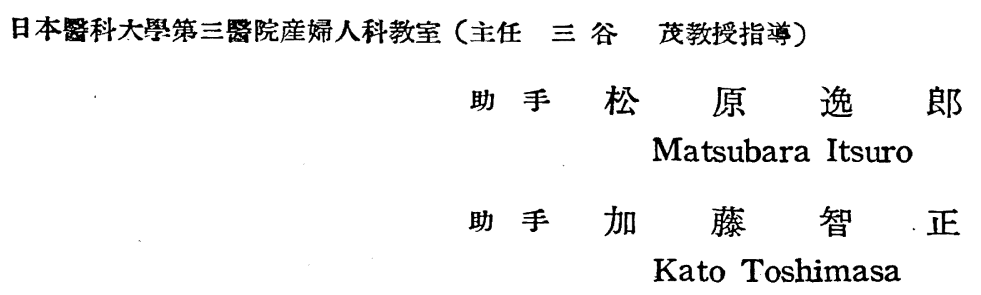

緒言

當呚室に於て, 臨床上興味あるクルツケンべ ルグ氏卵巢腫瘍の 2 例を經驗し，1例は術後14 日目に，突如として胃穿孔をきたし，不幸の轉 歸をとり，1例は原發廻盲部と共に卵巢腫瘍も 剔出したが, 時期既にをるく, 術後約 2 年にして 全身に轉移を起して, 死の轉歸をとる。兩例共,

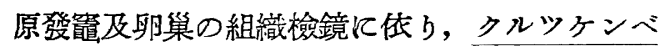
ルグ氏腫瘍を確診せる症例である。

\section{實 驗 例}

\section{症例第1.}

患者。23歳。未婚婦。家族歷, 既往 糜に特記すべきすのなし。初經來潮16歳。稍々 规不规則。最終月經は, 。昭和17年 1 月下旬より 3

日間。閉經以來，腹部が次第に膨隆して來るが 惡阻症狀はなく, 又1月頃より胃部疼痛を時々 訴人る事があつた。男性の交涉は極力否定した。 5 月に胸部「レ線寫眞と多量の胸部穿刺液を證 明することにより, 右側肋膜炎を併發したもの として, 某醫師より妊娠中絶の必要ありとて當 教室に送らる。

初診。昭和 17 年 5 月 4 日。體格中等。榮養不 良。胸部所見。右胸部全體に濁音を呈し, 呼吸

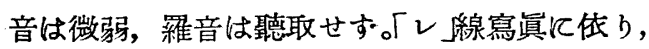
右胸部全體に除影が擴大してるる像が見られる が, 陰影の下界を見なかつた。血液沈降速度は、
大いに促進してるるが,「ッベルクリン」反應は 陰性である。

腹部所見。强度澎隆し腹水著明，子宮底と 思はれるものは, 臍上 2 指横經て觸れ，21糎， 頭部並びて慰部と思はれるものを觸知し，之は 浮球感著明であるが，胎兒心音は勿論聽取出來 ない。

内診所見。外陰, 腟飞異常なく, 腹水多量の ため, 内, 外兩診指の間仿, 丁度子宮の位置に 成人頭大の腫瘤を觸知する大である。腹部「レ」 線寫真で胎兒骨格を證明出來す，フリードマン 反應も陰性である。以上の所見に依り，之は妊 娠ではなく, 卵巢の兩側性, 實質性, 惡性腫演 であうて，そのために生じた多量の腹水が胸部 を押し上げ，所謂枷膜炎の症狀を起したものと 診斷す。侣入院後, 時々食後胃部疼痛があり, 嘔吐も 1 回あつたが, 吐物に血性のものを認め なかつた。

開腹所見。測 b得た淡黄色透明の腹水 $2500 \mathrm{cc}$ 子宮は尋常大, 右卵巢は成人頭大, 左卵巢は手 拳大, 灰白色, 凹凸不平, 餘り硬くない腫瘍で ある。之を摘出し手術を終る。腹腔を閉ぢる際 に胃部を見んとしたが，あまりにも高位にあつ たので，觸診して見たが腫瘤は觸れなかつた。

術後 2 日目江少量の吐血があり，5 日目治始 めて胃部に壓痛ある硬結を觸知したが，手術後 のため精細なる檢査も出來す，經過を觀察， 8 
$-80-(852)$

日目抜糸，12日目起坐，發熱全くなく，退院を 促してるた所，14日目に乫然劇烈なる胃部疼痛 發作あり，腹部は明瞭なる鼓音を呈し，脈膊頻 數, 細小となり, 最早再手術を施すの時機を逸 し, 翌15日目逐に胃穿孔に依る腹膜炎のため死 亡す。

死後家人の希望によつて手術創を切開して見 るに，瓦斯多量飞排出した。腹腔内に胃内容物 も證明せられた。胃を憸するに，幽門部後壁に 指頭を通する穿孔部位のあるのを知る，よつて 此の部位を剔出した。

組織的所見。左右共, 剔出卵巢腫瘍の肉眼的 に多少變化一樣ならすと思はれる所, 數ヶ所を 取つて切片とし、「ムチカルミン」其の他の染色 法を行つて鏡檢した。これによると腫瘍の漿膜 は結合繊維よりなり，表面に近い部分の組織は 緻密で表面に平行に走つてるるが，内部に至る て從つて, 鬆粗となり, 走行る不規則となつて るる, 此の基質の中に腫瘍細胞の浸潤を認める。 此の腫廈細胞は單獨に, 或は數個相集つて大, 小種々の所謂癌胞巢を形成してるる。然し何れ の切片に於ても, 卵巢固有の組織と思はれる所 見は全く認めることはできない，一般に血管に 乏しくて，中心部と䢬緗部とで特に大なる所見 の變化は見られぬ, 只比較的胞巢の像の著明な 所と, 不明瞭の所とは, 同一切片に於ても部位に より著しい差違がある。腫嘚細胞個々に就て見 るに, 原形質は濃淡多少の差違はあるが稍々赤 染し，核は「クロマチン」に稍々乏しい感があ る。原形質は豐富にして, 中に微細なる顆粒を 證明するものがある。其の大多數は硝子樣變性 に陷りて，一見空胞狀㹸られる，核の位置に よりては周邊に壓排せられて半月狀に見え, 所 謂印環細胞の像を呈してるる。此の印環細胞は 「ムチカルミン」染色によつてょく赤色に反應 し, 原形質の粘液變性に陷れることを知る。

死後剔出した胃幽門部は, 潰㾤を形成して, 小 指を通することも不可能である。潰汪面は小兒 の手掌大で, 殆んど幽門部の全周に涉つてるる, 潰瘍の周邊部は, 肥厚して 1 糎に達し, 中心部 は菲薄となり, 中心部に示指頭大の穿孔部位が
ある。穿孔周邊部を組織片として檢鏡するに， 表面は最早固有の粘膜を證明することは不可能

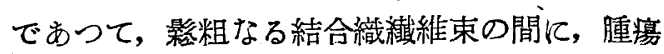
細胞の不規則に配列するのが見られる，此の腫 瘍細胞も, 所によりては所謂癌胞巢を形成する も，多くは繊維束間に浸潤するの像を呈してる る。個々の腫瘍細胞は, 卵巢腫瘍に於ける所見 と同樣であるが，所謂印環組胞は極めて少なく 存在することが, 卵巢腫湯の所見と異なる所で ある。

\section{症例第2.}

患者。 38 歳。 4 回經産婦。家族歷。 母親は子宮癌で死亡してるる。既往歷に特記す べものなし。初經來潮。16歳。正順。最終月 經は昭和18年7月16日より5 日間である。

現病歷。昭和18年1月, 廻“盲部沜卵大の壓 痛なき硬結に氣付き，6月頃より全身俋总感を 覺え，目立つて䇔湼して來た。7月，下腹部に 更に手拳大の腫瘤を自覺したが，今沦に胃腸障 碍もなく, 只 8 月10日に 3,4 回の嘔吐々, 下㢉 があつたので, 都内數ち所の病院を訪れ，胃腸 障碍, 附屬器腫湟等の診斷を受け手術苍鹰めら れて劏完を訪ふ。

初診。昭和 18 年 8 月16日。體格中等。榮養不 良。顔貌苦悶狀。可成の惡液質を認む。胸部異 常なし。

腹部所見。輕度に膨隆し，内，外診に依り恥 骨結合上緣江小兒頭大の凹凸不平，硬固，壓痛 のある移動性の腫瘤と, その直ぐ右側に鵎卵大 の腫瘤を觸れ, 又右側腎臟の位置に, 凹凸不平 硬固, 壓痛のない抵抗を觸れる。䀒, 脾臟は觸 知出來ない。血液沈降速度は大いに促進し, 犦 便に濳性出血を認め，「レ線寫眞に於て胃部に 變化なく，廻盲部 2 横指上部陰影が紐狀とな り, 强度の狹窄あるを知る。

開腹所見。腹水輕度, 右側卵巢に小兒頭大の 腫瘤があり，實質性にて，360度の莖捻轉を起 し, 壤腫の一部は破裂を來してるた。廻盲部に も超手拳大の腫瘤があり, 腹腔内に播種性の腫 瘍轉移を認めた。左側卵巢, 胃, 䀒臟等は肉眼 的, 觸診的に全く異狀ば認められない。雨側附 
屬器と共沉單純性子宮全剔出, 並びに廻盲部腫 瘍を上行結腸上部上り切断, 摘出, 廻腸々横行 結腸と飞腸吻合術を行ひ，淋巴腺の腫大せるも のも出來るだけ摘出し手術を終る。術後經過良 好にて19日目無事退院す。

術後35日目外來所見。體重は增加し全く健康 狀態にて何等異常を認めす。術後約 1 ケ年目外 來所見。榮養狀態變化なきも，下腹部飞約鷄卵 大腫瘤を觸知し, 胸骨上, 中央部の皮下に拇指 頭大の轉移を觸知す。以後の經過は戰爭劇烈々 なら，音信不通となつて確認する事は出來なか つたが, 其の後, 親戚の者より術後約 2 年にし て死亡せる事を確かめ得た。

組織的所見。卵巢腫瘍の數個所を切片として 種々の染色法を行ひ鏡檢した。これによると， 被膜は結合瀻維膜であつて, 内部は影粗な結合 織よりなる。腫瘍細胞は比較的大きく癌胞巢を 示すことが著明で，單獨に，或は $:-3$ 個集簇 するものは稀れである。勿論, 印環細胞は多數 認められ, 叉「ムチカルミン」に著明に反應し to

剔出した廻盲部は，肥厚して極めて硬く，割 を加ふるに, 健康部位との境界が極めて著明で ある。所によりては内腔壁から腠膜に及ぶ全層 か腫湯化して, 3糎几達する壁を形成してるる。 鏡檢するに勿論, 固有の粘膜の像は認むること ができ, 又筋層も證明することが不可能であ 而。而して腫瘍細胞は極めて大なる癌胞巢を形 成し, 其の周圍は菲薄な結合織膜にて境されて るる。此の腫演細胞の個々の境は, 胞巢の周邊 部に於ては著明で，原形質は豐富であるが，核
は縮少し，中心部に於ては全く核を認めない。 而して所謂印環細胞の像は極內て少ない。 「ムチカルミン」には極めてょく反應し, 全胞 巢が赤い塊の如く沉見られる。定型的なる粘液 細胞癌である。

\section{結論}

症例第 1 は, 妊娠症狀及び肺膜炎症狀の診断 溥念し，胃及腹水其の他の檢查を怠つたため に，逐に胃の穿孔による不幸の結果を取つたも のである。症例第 2 は, 手術前, 手術中に精細 なる他の臟器の檢查を行つたため, 手術の時期 は失したが，經過至極良好なる例であつた。こ 」に注意を要する事は, 卯巢望質性腫瘍, 殊江兩 側性實質性の惡性腫瘍と診斷した時は, 必す他 臟器の殊に卵巢に惡性轉移を起し易い, 胃腸管, 子宮等の精細なる檢查を手術前に, 又手術中に 女良く行ふ必要があり, 手術中移に轉移走發見 した時は, 引續き此等の腫場を切除し, 切除不 可能の時は,「レ腺照射等の處置を必要とする

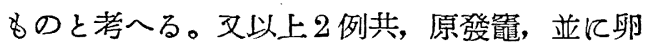
巢腫湯の組織檢鏡に依り,クルツケンベルグ氏 腫瘍なることを確認した。

稿を終るに當り, 御愁篤なる御指導と御校閱 を賜つた恩師三谷茂呚授に對し, 梁甚なる謝意 を表します。

此の論文の要旨は昭和 18 年 10 月 24 日, 日本醫 科大學學會に於て報告した。

$$
\text { 交献 }
$$

三浦氏論交中の文献と同㥞なるにより省略。 